\title{
Effect of Individual Characteristics, Work Environment, and Work Motivation on Performance of Madrasah Teachers
}

\author{
Risto Munandar ${ }^{1}$ Yasri $^{2}$, Sulastri ${ }^{3}$ \\ ${ }^{1}$ Universitas Negeri Padang, Padang and Indonesia \\ 2 Universitas Negeri Padang, Padang and Indonesia, $\square$ yasri33@fe.unp.ac.id \\ ${ }^{3}$ Universitas Negeri Padang, Padang and Indonesia, $₫$ lastri_feunp@yahoo.com
}

\begin{abstract}
This study aims to analyze the effect of work environment, individual characteristics and work motivation on teacher performance. The population of this study was conducted in Private Madrasah of Candung and Ampek Angkek Subdistrict, Agam District, West Sumatra with a total sample of 100 respondents. The analysis technique used is PLS SEM (Partial Least Square). The results of the study are: (1). Individual characteristics have a positive and significant effect on teacher performance; (2). Work Environment has a positive and significant effect on teacher performance; (3) Motivation does not have a significant effect on teacher performance; (4). Individual characteristics do not significantly influence teacher performance; (5). Work environment does not have a significant effect on teacher performance.
\end{abstract}

Keywords: Individual Characteristics; Work environment; Work motivation; Performance

\section{Introduction}

Teachers as human resources are driving factors in an organization. Human factors will be included as a factor that holds control over the organization. According to (Handoko, 2000: 195) teacher performance problems is basically about issues that are related to aspects of human resources, because Teacher performance is closely related to the achievements and results achieved by the organization. The successful implementation of the duties of a teacher depends on the capability level of a person in carrying out their duties, because the teacher is responsible for the task and the work that is better in accordance with the goals set.

According to Zulkifli (2014) teacher performance can be accessed by several factors: 1) Formulate learning objectives in lesson plans according to the curriculum; 2) Compile teaching materials in a continuous, logical, contextual and up-to-date; 3) Plan effective learning activities; 4) Chooses learning resources or learning media in accordance with the material and learning strategies; 5) Learning effectively; 6) Controls learning material; 7) Applies an effective learning strategy approach; 8) Utilizes learning resources / media; 9) The teacher triggers student involvement in learning; 10) Uses the right and proper language in learning; 11) The teacher ends learning effectively; 12) Designs evaluation tools to measure the progress and success of students; 13) Uses various strategies and assessment methods to monitor the progress and learning outcomes of students; 14) Makes use of various assessment results to give feedback to students about their learning progress and the material for preparing the next learning design.

Ingvarson (2007) explains that something must be fulfilled in a teacher's performance such as: (1) Government regulations and requirements. This category includes laws, codes, and country program guidelines; (2) Professional standards. Like professional standards for teaching, teacher competency standards in student education assessments; (3) Results of teaching. Such as student assessment results, number and type of disciplinary references, application of skills learned in training programs, and number of resources used; (4) Theory is based on practice. Teaching theory, learning and cognition, cognitive psychology teaching, and cognitive development of teachers are basic examples in this category; (5) what the teacher does. In this category see what the teacher does and use the results of the effort; (6) what other people want the teacher to do. Examples include the use of certain 
teaching styles, peer preferences and supervisors, and the wishes of clients and stakeholders such as students, parents, prospective students, community members; (7) what the teacher should do.

According to Mathis (2006) there are several factors that influence the performance of individual workers, including: 1) Ability, 2) motivation, 3) support received, 4) the existence of the work they do and 5) their relationship with the organization. According to Tumilaar (2015) performance can be influenced by discipline, leadership style and motivation. According to Musriha (2013) performance can be determined by individual characteristics, organizational culture, and career development. According to Tulenan (2015), there are several factors that influence performance such as work environment and compensation. Based on some of these opinions show that performance can be influenced by many factors, but in this study based on phenomenon and object of research, teacher performance is limited by several factors such as work environment, individual characteristics and work motivation.

Heck (2007) explains teacher quality is determined based on knowledge, experience, training and credentials; general intellectual skills; or class effectiveness related to student learning achievement. So, if the decline in student learning outcomes means a decrease in teacher performance in the teaching and learning process as shown by the performance of private Madrasah teachers in Candung and Ampek Angkek sub-districts that showed the low scores of the student exams and national examinations.

Individual characteristics can affect performance, because someone who has a young age will be more enthusiastic and stamina in work, as well as gender, and the attitude greatly influences performance at work. According to Musriha (2013) Individual Characteristics have a significant effect on performance. This was also stated by Setiawan (2013) arguing that individual characteristics and work environment had a significant effect on performance. Individual's characteristics play an important role in improving teacher performance.

The next factor that affects teacher performance is the work environment. Bakker's research (2010) showed that work environment can increase teacher work engagement, and indirectly have a positive effect on teacher performance. Siddiqi (2018) explains that work environment has a significant effect on performance. Tulenan (2015) was found that the work environment has a significant effect on performance, so the better the work environment will lead to a higher performance of a person. Mathews (2016) showed that the work environment has a positive effect on improve performance.

Work motivation affects teacher performance. Motivation has a significant effect on performance. The better the motivation, the higher the teacher's performance. According to Muchtar (2016) that motivation and work environment have a significant effect on performance. According to Tumilaar (2015) explained that motivation has a significant effect on performance.

Based on the description above, the writer is interested analyze the Effect of individual characteristics, work environment, and work motivation on the performance of private Madrasah teachers in the Candung and Ampek Angkek Sub-district.

\section{Methods}

This research is quantitative research that explains the effect of the work environment, individual characteristics and work motivation on teacher performance. This research was conducted in Private Madrasah of Candung and Ampek Angkek Subdistrict, Agam District, West Sumatra Province to see an overview of the influence of Individual Characteristics, Work Environment and Motivation on Employee Performance and Teachers and examine the significance effect of the independent variable on the dependent variable partially.

In this study the sampling collected by the proportional stratified random sampling method because the population has diverse and multilevel characteristics, this method by sampling population members randomly and carried out by taking a percentage of the population based on certain in the population. The criteria used for sampling are based on Private Madrasah Teachers in Candung and Ampek Angkek Sub-districts. The number of samples in this study amounted to 100 
people. Data analysis techniques used in this study are quantitative analysis using the PLS (Partial Least Square) model.

\section{Results and Discussion}

Outer Model Test (Measurement Model)

Convergent validity is tested using the value of outer loading. An indicator is stated to meet convergent validity in a good category if the value of outer loading is $>0.6$. Based on the results of the convergent validity test, it is known that each indicator of the research variable has a value of outer loading $>0.6$. However, there are still a number of indicators that have an outer loading $<0.6$ are KI_04 (0.586), KJ_01 (0.473), KJ_02 (0.472), KJ_04 (0.426), KJ_08 (0.475), KJ_13 (0.450), LK_04 (0.530), LK_05 (0.564), LK_12 (0.534), LK_13 (0.579). According to Chin as quoted by Ghozali (2014), the value of outer loading between 0.5 - 0.6 is considered sufficient to meet the convergent validity requirements. The results above show there are several variable indicators whose outer loading value is below 0.5 So that the indicator is invalid and excluded from the research model. Valid indicator is obtained with the following results:

Table 1 Outer Loading After Valid

\begin{tabular}{|c|c|c|}
\hline Variable & Indicators & Outer Loading \\
\hline \multirow{5}{*}{$\begin{array}{l}\text { Individual } \\
\text { Characteristics }\end{array}$} & KI_01 & 0.708 \\
\hline & KI_02 & 0.630 \\
\hline & KI_03 & 0.902 \\
\hline & KI_05 & 0.883 \\
\hline & KI_06 & 0.704 \\
\hline \multirow[t]{9}{*}{ Performance } & KJ_03 & 0.917 \\
\hline & KJ_05 & 0.659 \\
\hline & KJ_06 & 0.912 \\
\hline & KJ_07 & 0.902 \\
\hline & KJ_10 & 0.726 \\
\hline & KJ_11 & 0.804 \\
\hline & KJ_12 & 0.647 \\
\hline & KJ_14 & 0.722 \\
\hline & KJ_15 & 0.79 \\
\hline \multirow[t]{12}{*}{ Work environment } & LK_01 & 0.848 \\
\hline & LK_02 & 0.849 \\
\hline & LK_03 & 0.902 \\
\hline & LK_06 & 0.737 \\
\hline & LK_07 & 0.803 \\
\hline & LK_08 & 0.856 \\
\hline & LK_09 & 0.864 \\
\hline & LK_10 & 0.912 \\
\hline & LK_11 & 0.817 \\
\hline & LK_14 & 0.666 \\
\hline & LK_15 & 0.87 \\
\hline & LK_16 & 0.642 \\
\hline \multirow[t]{2}{*}{ Work motivation } & MK_01 & 0.788 \\
\hline & MK_02 & 0.714 \\
\hline
\end{tabular}


Table Cont...

\begin{tabular}{ll} 
MK_03 & 0.733 \\
\hline MK_04 & 0.866 \\
\hline MK_05 & 0.854 \\
\hline MK_06 & 0.627 \\
\hline MK_07 & 0.697
\end{tabular}

Source: Processed Primary Data (2019)

The results show that there is no indicator whose outer loading value is below 0.5 , all indicators are declared feasible or valid for research use and can be used for further analysis.

Discriminant validity testing is to prove the indicator the largest loading factor in the construct than loading factors with other constructs. Cross loading can be seen in the following table:

Table 2 Cross Loading

\begin{tabular}{|c|c|c|c|c|c|}
\hline Variable & Indicators & KI & KJ & LK & MK \\
\hline \multirow{5}{*}{$\begin{array}{l}\text { Individual } \\
\text { Characteristics }\end{array}$} & KI_01 & 0.708 & 0.502 & 0.421 & 0.475 \\
\hline & KI_02 & 0.630 & 0.476 & 0.387 & 0.322 \\
\hline & KI_03 & 0.902 & 0.723 & 0.565 & 0.462 \\
\hline & KI_05 & 0.883 & 0.675 & 0.549 & 0.424 \\
\hline & KI_06 & 0.704 & 0.581 & 0.424 & 0.354 \\
\hline \multirow[t]{9}{*}{ Performance } & KJ_03 & 0.701 & 0.917 & 0.593 & 0.502 \\
\hline & KJ_05 & 0.531 & 0.659 & 0.537 & 0.393 \\
\hline & KJ_06 & 0.728 & 0.912 & 0.563 & 0.580 \\
\hline & KJ_07 & 0.686 & 0.902 & 0.602 & 0.445 \\
\hline & KJ_10 & 0.517 & 0.726 & 0.397 & 0.396 \\
\hline & KJ_11 & 0.640 & 0.804 & 0.531 & 0.402 \\
\hline & KJ_12 & 0.529 & 0.647 & 0.514 & 0.399 \\
\hline & KJ_14 & 0.487 & 0.722 & 0.435 & 0.362 \\
\hline & KJ_15 & 0.643 & 0.790 & 0.519 & 0.464 \\
\hline \multirow[t]{13}{*}{ Work environment } & LK_01 & 0.528 & 0.515 & 0.848 & 0.405 \\
\hline & LK_02 & 0.485 & 0.512 & 0.849 & 0.423 \\
\hline & LK_03 & 0.501 & 0.560 & 0.902 & 0.445 \\
\hline & LK_06 & 0.514 & 0.454 & 0.737 & 0.382 \\
\hline & LK_07 & 0.518 & 0.547 & 0.803 & 0.500 \\
\hline & LK_08 & 0.485 & 0.548 & 0.856 & 0.506 \\
\hline & LK_09 & 0.533 & 0.577 & 0.864 & 0.479 \\
\hline & LK_10 & 0.505 & 0.577 & 0.912 & 0.483 \\
\hline & LK_11 & 0.552 & 0.520 & 0.817 & 0.412 \\
\hline & LK_14 & 0.463 & 0.532 & 0.666 & 0.399 \\
\hline & Table Coun & & & & \\
\hline & LK_15 & 0.487 & 0.557 & 0.870 & 0.468 \\
\hline & LK_16 & 0.446 & 0.566 & 0.642 & 0.394 \\
\hline \multirow[t]{4}{*}{ Work motivation } & MK_01 & 0.355 & 0.409 & 0.404 & 0.788 \\
\hline & MK_02 & 0.330 & 0.420 & 0.436 & 0.714 \\
\hline & MK_03 & 0.394 & 0.478 & 0.364 & 0.733 \\
\hline & MK_04 & 0.406 & 0.431 & 0.437 & 0.866 \\
\hline
\end{tabular}


Table Cont...

\begin{tabular}{lllll} 
MK_05 & 0.457 & 0.431 & 0.480 & $\mathbf{0 . 8 5 4}$ \\
\hline MK_06 & 0.419 & 0.418 & 0.338 & $\mathbf{0 . 6 2 7}$ \\
\hline MK_07 & 0.440 & 0.365 & 0.412 & $\mathbf{0 . 6 9 7}$ \\
\hline
\end{tabular}

Source: Processed Primary Data (2019)

Based on the data in table 2, it can be seen that each indicator in the research variable has the largest cross loading value in the variables it forms compared to the cross-loading value in the other variables. Based on the results, it can be stated that the indicators used in this study have good discriminant validity. Discriminant validity can also be known through other methods by looking at the average variant extracted (AVE) value for each indicator, the value must be $>0.5$ for a good model with the following results:

Table 3 Average Variant Extracted (AVE)

\begin{tabular}{ll}
\hline Variable & Average Variance Extracted (AVE) \\
\hline Individual Characteristics & 0.597 \\
\hline Performance & 0.629 \\
\hline Work environment & 0.669 \\
\hline Work motivation & 0.575
\end{tabular}

Source: Processed Primary Data (2019)

Based on the data presented in table 3, The AVE value of Individual Characteristics, Performance, Work Environment and Work Motivation variables greater than 0.5. It can be stated that each variable has good discriminant validity.

\section{Reliability Test}

Reliability test is the next step by researchers to test the instrument. PLS also uses reliability testing to measure the internal consistency of a measuring instrument. Reliability shows accuracy, consistency of a measuring instrument in making measurements. Reliability testing in PLS can use two methods by Cronbach's alpha and Composite reliability. According to Hair et al. (2014) the Cronbach's coefficient and composite reliability must be greater than 0.7 even though the value of 0.6 is still acceptable.

Cronbach's alpha and Composite reliability coefficients that show a value $<0.6$ indicate that reliability is considered bad, but can still be used for further analysis, and if the Cronbach's alpha and Composite reliability coefficients show values of 0.6 to 0.7 , reliability can be accepted, then if the Cronbach alpha coefficient and Composite reliability show a value of 8 to 0.8 then reliability is good (Cooper and Schindler, 2014).

From the output of the Smart-PLS, all constructs have a composite reliability value $>0.70$ and Cronbach's alpha $>0.60$. It can be concluded that the construct has good reliability

Table 4 Cronbach's alpha and Composite Reliability

\begin{tabular}{llrl}
\hline Variable & $\begin{array}{l}\text { Cronbach's } \\
\text { Alpha }\end{array}$ & \multicolumn{2}{c}{$\begin{array}{l}\text { Composite } \\
\text { Reliability }\end{array}$} \\
\hline Individual Characteristics & & 0.825 & 0.879 \\
\hline Performance & 0.923 & 0.973 \\
\hline Work environment & 0.954 & 0.960 \\
\hline Work motivation & 0.874 & 0.904
\end{tabular}

Source: Processed Primary Data (2019)

\section{Structural Models Testing (Inner Model)}

The structural model in PLS is evaluated by using the path coefficient value for the independent variable then evaluates its significance based on the t-statistical value of each path 
Table 5 Results of Direct Influence

\begin{tabular}{lcccc}
\hline & $\begin{array}{c}\text { Path } \\
\text { Coefficient }\end{array}$ & $\begin{array}{c}\text { Standard } \\
\text { Deviation } \\
\text { (STDEV) }\end{array}$ & $\begin{array}{c}\text { T } \\
\text { Statistic }\end{array}$ & P Value \\
\hline $\begin{array}{l}\text { Individual Characteristics on } \\
\text { Performance }\end{array}$ & 0.550 & 0.077 & 7.170 & 0.000 \\
\hline $\begin{array}{l}\text { Individual Characteristics on } \\
\text { Work Motivation }\end{array}$ & 0.315 & 0.107 & 2.942 & 0.003 \\
\hline $\begin{array}{l}\text { Work Environment on } \\
\text { Performance }\end{array}$ & 0.255 & 0.078 & 3.278 & 0.001 \\
\hline $\begin{array}{l}\text { Work Environment on Work } \\
\text { Motivation }\end{array}$ & 0.350 & 0.117 & 3.001 & 0.003 \\
\hline $\begin{array}{l}\text { Work Motivation on } \\
\text { Performance }\end{array}$ & 0.128 & 0.068 & 1.895 & 0.059 \\
\hline
\end{tabular}

Source: Processed Primary Data (2019)

Based on the description of the results, it shows that the variables in this model have a path coefficient with positive numbers. If the path coefficient value is greater on an independent variable on the dependent variable, the influence of the independent variables on the dependent variable will be stronger. But the results show that work motivation does not have a significant effect on performance.

Then the results of indirect effects, the influence of individual characteristics on performance through work motivation and the influence of the work environment on performance through work motivation can be seen in the following table:

Table 6 Results of Indirect Effects

\begin{tabular}{lrrrrr}
\hline & $\begin{array}{l}\text { Path } \\
\text { Coefficient }\end{array}$ & $\begin{array}{l}\text { Standard } \\
\text { Deviation } \\
\text { (STDEV) }\end{array}$ & T Statistic & P Value \\
\hline $\begin{array}{l}\text { Individual characteristics on } \\
\text { performance through work motivation }\end{array}$ & 0.040 & 0.027 & 1.522 & 0.129 \\
\hline $\begin{array}{l}\text { Work environment on performance } \\
\text { through work motivation }\end{array}$ & 0.045 & 0.029 & 1.562 & 0.119 \\
\hline
\end{tabular}

Source: Processed Primary Data (2019)

Based on the results, individual characteristics have no significant effect on performance through work motivation because $p$ value greater than the significance level of $0.05(0.129>0.05)$. The work environment has no significant effect on performance through work motivation with $\mathrm{p}$ value greater than the significance level of $0.05(0.119>0.05)$. 


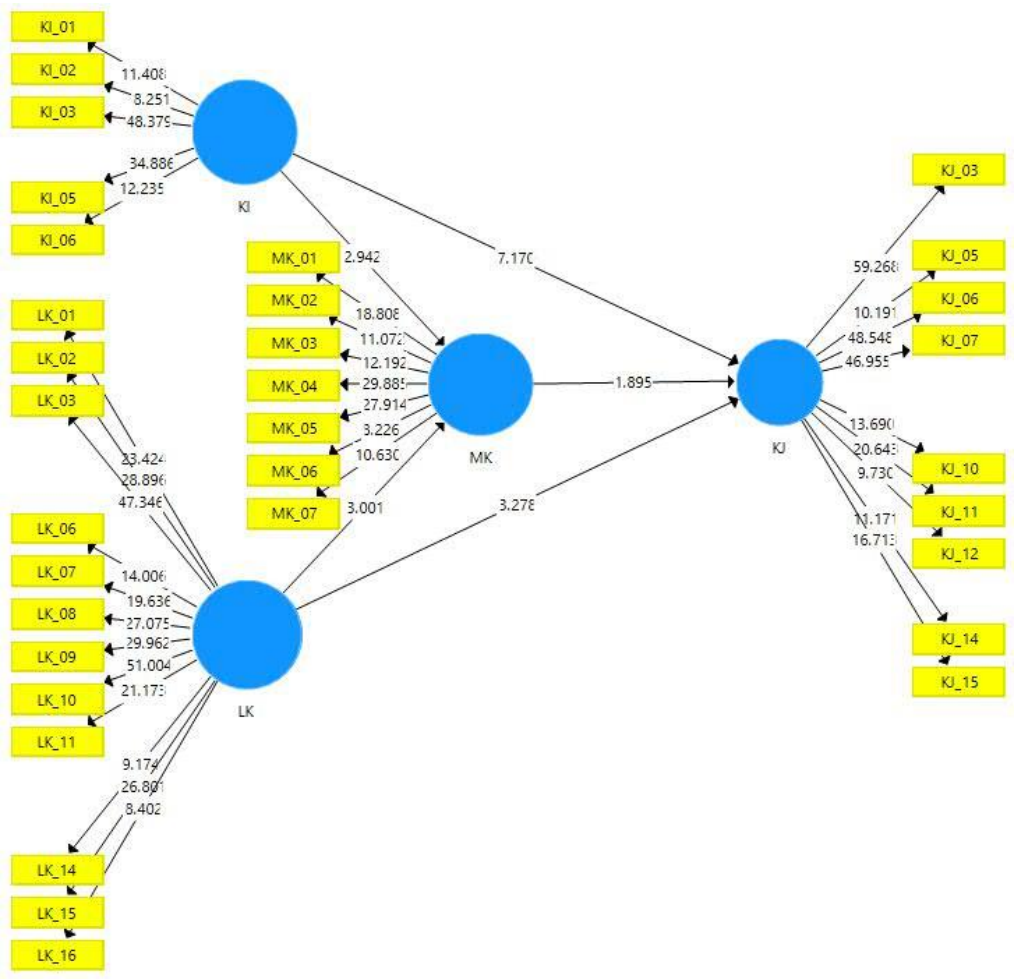

Figure 1 Inner Model

Based on the results of testing the hypothesis above, it can be summarized in the following table:

Table 7 Hypothesis Testing Results

\begin{tabular}{lll}
\hline Hypothesis & Significance & Results \\
\hline $\begin{array}{l}\text { Individual characteristics on performance of } \\
\text { private Madrasah teachers in Candung and }\end{array}$ & $0,000<0,05$ & Accepted \\
Ampek Angkek sub-districts & \\
\hline $\begin{array}{l}\text { Work Environment on performance of Private } \\
\text { Madrasah teachers in Candung and Ampek }\end{array}$ & & \\
Angkek Sub-districts & Accepted \\
\hline $\begin{array}{l}\text { Work motivation on performance of private } \\
\text { Madrasah teachers in Candung and Ampek }\end{array}$ & \\
Angkek sub-districts & Rejected \\
\hline $\begin{array}{l}\text { Individual characteristics on performance } \\
\text { through work motivation of private Madrasah }\end{array}$ & \\
teachers in Candung and Ampek Angkek sub- \\
districts
\end{tabular}

\section{Discussion}

Based on the results, the individual characteristics have a positive and significant effect on the performance of private Madrasah teachers in Candung and Ampek Angkek sub-districts. Individual characteristics have a significant effect on performance, individual characteristics make a high contribution to the performance of private Madrasah teachers in Candung and Ampek Angkek subdistricts. Individual characteristics as self-confidence exist within themselves, the role of abilities, and social relationships (Sakti, 2014). Individual characteristics are closely related to performance, there is 
a significant effect of individual characteristics on employee performance. Individual characteristics play an important role in individual success. Among all individual characteristics, five factors can be accepted and are most commonly used by researchers and practitioners to evaluate individual characteristics. These five factors are extraversion, agreeableness, conscientiousness, emotional stability, and openness or intellectuality (Bhatti, 2013).

Every human being has individual characteristics that are different from one another. The most important resources in the organization are human resources, people who provide energy, talent, creativity, and their efforts to the organization. According to Musriha (2013) individual characteristics have a significant effect on performance. Setiawan (2013) arguing that individual characteristics and work environment have a significant effect on employee performance

Work environment has a positive and significant effect on the performance of private Madrasah teachers in Candung and Ampek Angkek sub-districts. Work environment variables have a significant effect on performance, the work environment contributes highly to the performance of private Madrasah teachers in Candung and Ampek Angkek sub-districts. The work environment is a factor needed to improve individual performance. Managerial support, co-worker's encouragement, adequate resources, opportunities to apply learned skills, and technical support in training transfers (Suhepi, 2018). In general, the environment cannot be controlled by the company so the company must adjust to the environment (Riyanto, 2017).

The work environment influences teacher performance. Research conducted by Muchtar (2016), the work environment has a significant effect on performance. Tulenan (2015) was found that the work environment has a significant effect on performance, so the better the work environment will lead to a higher performance of a person. While Mathews (2016) showed that the work environment has a positive effect to improve performance.

Work motivation did not significant effect on performance of private Madrasah teachers in Candung and Ampek Angkek sub-districts. High and low work motivation does not affect the level of teacher performance significantly. Work motivation variables have no significant effect on performance; work motivation does not provide a high contribution to the performance of private Madrasah teachers in Candung and Ampek Angkek sub-districts.

Motivation is the key to successful organizations to maintain work continuity in a strong way and help the organization to survive. Motivation is to find needs within employees and help to achieve them with a smooth process. Motivating employees leads to broadening their skills to meet the demands of the organization (Omollo, 2015). But if someone is not motivated in his work certainly will not improve his performance.

Motivation drives behaviour that gives direction to the goal and underlies the tendency to keep showing behaviour. Motivation has a significant effect on performance. According to Muchtar (2016) that motivation and work environment have a significant effect on performance. According to Tumilaar (2015) explained that motivation has a significant effect on employee performance.

Individual characteristics did not significantly effect on teacher performance through the work motivation of private Madrasah teachers in Candung and Ampek Angkek sub-districts. The better individual characteristics will not improve teacher performance through work motivation. Individual positive variables have no significant effect on performance through work motivation, individual characteristics do not contribute significantly to performance through the motivation of private Madrasah teachers in Candung and Ampek Angkek sub-districts.

Personal characteristics such as age, gender, and marital status affect several variables such as job satisfaction, employee turnover, and performance. Personality is a characteristic that can be considered relatively stable, while moods are characteristics that can change over time. A positive mood will create opportunities for someone to help others. Moods are influenced by personality; moods are also influenced by situations, such as working group climate and organizational factors (Nimran, 2011). Sometimes external factors can influence individual characteristics whether or not they affect their performance. 
Mathews (2016) showed that there is a significant effect of individual characteristics on work motivation and performance. Based on the results of the analysis indicate that there is a significant influence on individual characteristics of the ability of employees. There is a significant effect on job satisfaction on performance; there is an effect of work motivation on job satisfaction. Furthermore, Nuckcheddy's research (2018) shows that personality is an important topic that must be considered by management because they seek to increase workers' motivation and optimize organizational behaviour in the workplace. Based on the research model proposed by Jakfar (2014) showed the relationship between individual characteristics and motivation.

Work environment does not have a significant effect on teacher performance through the work motivation of private Madrasah teachers in Candung and Ampek Angkek sub-districts. The better working environment will not improve teacher performance through teacher motivation. The work environment is around the employee and can affect the way do the job (Omari, 2017). Certain factors such as low work motivation can determine the influence of the work environment on performance; it will have a significant effect or not affect performance.

The results of Sutanto's research (2018) showed that organizational justice and work environment have a positive and significant effect on employee motivation, both individually and collectively. Employees who have worked in the company for a long time continue to stay in the company because of the good treatment they received from the company, good relationships with employees and other management, and the security feelings that the company gives them. Furthermore, the results of Saeed's research (2016) showed that there was a significant and positive effect of the Work Environment on Motivation and there was also a positive influence on Motivation on Job Satisfaction. The results showed that motivation mediates partially between the work environment and job satisfaction of school teachers. Then based on the research model proposed by Siddiqi (2018), there is a relationship between work environment and work motivation that affects performance.

\section{Conclusion}

Based on the results of the analysis and discussion, the authors obtained conclusions that can be drawn from the research as follows: (1). Individual characteristics have a positive and significant effect on teacher performance; (2). Work Environment has a positive and significant effect on teacher performance; (3) Motivation does not have a significant effect on teacher performance; (4). Individual characteristics do not significant effect on teacher performance; (5). The work environment does not have a significant effect on teacher performance.

The suggestions to improve the performance of private Madrasah teachers in Candung and Ampek Angkek Sub-Districts are expected from the results of this study to Improve individual teacher characteristics by increasing honesty in work, have goals and hopes for the future, have stable emotions and feelings, have creative thoughts and ideas, increase knowledge about work, and be able to evaluate personal self. Then improve the work environment by: (1) Improve the physical work environment such as the presence of school air from dust, good lighting in the classroom, good lighting in the teacher's office room, complete facilities and infrastructure in the classroom and teacher's room; (2) Improve relations with coworkers such as the existence of a good relationship with fellow teachers in work, good communication between fellow teachers in work, helping fellow teachers in completing work, and establishing good cooperation between fellow teachers in doing a job; (3) Improve the safety, security and working hours by increasing the sense of comfort in work, the effective sharing of working hours, and improve the School environment as the work environment meets expectations; (4) Improve the non-physical work environment such as provide sufficient information related to the work, gives freedom to teachers in carrying out the work, the gives responsibility to all teachers, and concerned with the difficulties faced work. Furthermore, increasing teacher work motivation by: (1) Increase teacher intrinsic motivation by increase the sense of responsibility for the work, work optimally to obtain good work performance, encourage teachers to always develop the potential that exists in themselves, and provide the right to decide subject 
related to work; (2) Increase extrinsic motivation by giving rewards for what is done for work and providing additional salary (incentives) in accordance with the achievements.

\section{References}

Al-omari, K., \& Okasheh, H. (2017). The Influence of Work Environment on Job Performance : A Case Study of Engineering Company in Jordan. International Journal of Applied Engineering Research, 12(24), 15544-15550.

Ali, A., Bin, L. Z., \& Ali, Z. (2016). The Impact of Motivation on the Employee Performance and Job Satisfaction in IT Park (Software House) Sector of Peshawar, Pakistan. International Journal of Academic Research in Business and Social Sciences, 6(9), 297-310.

Altindis, S. (2011). Job motivation and organizational commitment among the health professionals : A questionnaire survey. African Journal of Business Management, 5(21), 8601-8609.

Bakker, A. B., \& Bal, P. M. (2010). Weekly work engagement and performance: A study among starting teachers. Journal of Occupational and Organizational Psychology, 83, 189-206.

Bhatti, M. A. (2013). Effects of individual characteristics on expatriates' adjustment and job performance. European Journal of Training and Development, 37(6), 544-563.

Cheek, N. N. (2018). Aspects of identity : From the inner-outer metaphor to a tetrapartite model of the self. Self and Identity, 17(4), 1-16.

Hammond, L. D. (2012). Evaluating teacher evaluation. Phi Delta Kappan, 93(6), 8-15.

Heck, R. H., \& Heck, R. H. (2007). Educational Administration Quarterly and Students ' Achievement and Growth Rates. Educational Administration Quarterly, 43, 399-431.

Ingvarson, L., \& Rowe, K. (2007). Conceptualising and Evaluating Teacher Quality : Substantive and methodological issues. The Economics of Teacher Quality Conference, (February), 1-27.

Jakfar, A. A. (2014). Influence of Individual Characteristics, Organizational Culture and Work Motivation to Satisfaction and Performance of Hand-Rolled Cigarette Workers at the Cigarette Industry in Madura, 3(1).

Jogiyanto. (2009). Sistem Informasi Manajemen. Yogyakarta: Andi.

Joseph, B. (2015). The effect of employees ' motivation on organizational performance. Journal of Public Administration and Policy Research, 7(May), 62-75.

Joseph, I. (2016). Analysis The Influence Of Physical Work Environment And Non-Physical Work Environment On Employee Productivity In General Hospital Gmim Kalooran Amurang South Minahasa Regency . Jurnal Berkala Ilmiah Efisiensi, 16(04), 407-420.

Mangkunegara, A. P. (2016). Effect of Training, Motivation and Work Environment on Physicians ' Performance Anwar Prabu Mangkunegara Rela Agustine. Academic Journal of Interdisciplinary Studies, 5(1), 173-188.

Mathews, C., \& Khann, I. K. (2016). Impact of Work Environment on Performance of Employees in Manufacturing Sector in India: Literature Review. International Journal of Science and Research, 5(4), 2013-2016.

Mathis, R. L. (2006). Human Resource Management. Jakarta: Salemba Empat.

Mayangsari, A. S. (2014). The Analysis of The Effect of Individual Characteristics and Supervisor Support on Motivation and Learning Transfer. British Journal of Economics, Management \& Trade, 5(3).329-337.

Muchtar. (2016). The Influence of Motivation and Work Environment on The Performance of Employees. Journal SINERGI, 6(2).27-40.

Mulyasa, E. (2011). Standar Kompetensi dan Sertifikasi Guru. Bandung: PT Remaja Rosdakarya.

Musriha. (2013). The Impact of Individual Characteristics and Organization Culture on Performance and Career Development of Employees Case studies Five Star Hotel in Surabaya Indonesia. Journal of Business and Management, 14(3), 21-27.

Narasuci, W. (2018). Effect Of Work Environment On Lecturer Performance Mediated By Work Motivation And Job Satisfaction. Journal of Applied Management, 16(4), 645-653.

Nimran, U. (2011). Relationships between Individual Characteristics of Employees and 
Organizational Climate with Organizational Citizenship Behavior (OCB). J. Basic. Appl. Sci. Res., 1(11), 2310-2313.

Nuckcheddy, A. (2018). The Effect of Personality on Motivation and Organisational Behaviour. Psychology and Behavioral Science International Journal, 9(2).

Omollo, P. A. (2015). Effect of motivation on employee performance of commercial banks in Kenya: A case study of Kenya Commercial Bank in Migori County Pamela. International Journal of Human Resource Studies, 5(2), 87-103.

Raziq, A., \& Maulabakhsh, R. (2015). Impact of Working Environment on Job Satisfaction. Procedia Economics and Finance, 23(October 2014), 717-725.

Ridwan. (2006). Aplikasi Statistika dan Metode Penelitian. Untuk Administrasi dan Manajemen. Bandung: Dewa Ruci.

Riyanto, S., Sutrisno, A., \& Ali, H. (2017). The Impact of Working Motivation and Working Environment on Employees Performance in Indonesia Stock Exchange. International Review of Management and Marketing, 7(3), 342-348.

Robbins, S. P. (2008). Perilaku Organisasi (Organizational Behavior). Jakarta: Salemba Empat.

Saeed, H. M. I., \& Nasir, N. (2016). Work Environment on Job Satisfaction with mediating effect of Motivation among School Teachers in Lahore, Pakistan. Journal of Management Engineering and Information Technology, 3(6).

Sakti, I., Hadiwijoyo, D., \& Rochman, F. (2014). The Effect Individual Characteristics , Strength Groups, Emotional Exhaustion, Organization Citizenship Behavior To Job Satisfaction And Service Sabotage In Restaurant Bekasi City West Java , Indonesia. International Journal of Business and Management Invention, 3(9), 41-50.

Samson, G. N. (2015). Effect of Workplace Environment on the Performance of Commercial Banks Employees in Nakuru Town. International Journal of Managerial Studies and Research, 3(12), 76-89.

Secan, H. (2014). Monitoring of Educational Indikators in Higher Education: A Comparison of Perceptions. Journal Educational Sciences Theory \& Practice ISSN, 15(2).359-376.

Setiawan, J. (2013). Pengaruh Karakteristik Individu dan Lingkungan Kerja Terhadap Kinerja Karyawan pada PT. Awetama Bina Reksa. Jurnal AKMENBIS, 2(1).55-70.

Shahzadi, I. (2014). Impact of Employee Motivation on Employee Performance. European Journal of Business and Management, 6(23), 159-167.

Shavelson, R. J., \& Stern, P. (1981). Research on Teachers' Pedagogical Thoughts, Judgments, Decisions, and Behavior. Review of Educational Research, 51(4), 455-498.

Siddiqi, T. (2018). Impact Of Work Environment, Compensation And Motivation On The Performance Of Employees In The Insurance Companies Of Bangladesh. South East Asia Journal of Contemporary Business, Economics and Law, 15(5), 153-162.

Sugiyono. (2015). Metode Penelitian Manajemen. Bandung: Alfabeta.

Suhepi, A. (2018). The Influence Of Training Design, Individual Characteristics, And Work Environment On Training Transfer And Its Impact On Employee' S Performance. International Journal of Economics, Commerce and Management, 6(3), 103-123.

Sutanto, E. M. (2018). Organizational Justice Work Environment And Motivation. International Journal of Business and Society, 19(2), 313-322.

Taylor, B. E. S., \& Tyler, J. H. (2012). The Effect of Evaluation on Teacher Performance. American Economic Review, 102(7), 3628-3651.

Tulenan, S. (2015a). The Effect of Work Environment and Compensation Toward Employee Performance at The Office of State Assets and Auction Service Manado. Journal EMBA, 3(3).672682.

Tulenan, S. (2015b). The Effect Of Work Environment And Compensation Toward Employee Performance At The Office Of State Assets And Auction Service Manado. Jurnal EMBA, 3(3), 672-682.

Tumilaar, B. R. (2015). The Effect of Discipline, Leadership, and Motivation on Employee Performance at BPJS Ketenagakerjaan Sulut. Jurnal EMBA, 3(2).787-797. 
Zulkifli, M. (2014). Motivasi Kerja, Sertifikasi , Kesejahteraan. Persona, Jurnal Psikologi Indonesia, 3(02), 148-155. 